\title{
Teaching English as a Foreign Language in Pandemic Times
}

\author{
Joana Taci \\ Phd., University “Eqrem Çabej”, Gjirokaster, Faculty of \\ Social Sciences, Department of Foreign Languages
}

\begin{abstract}
In general, teaching, as a multidimensional process, has always been considered as a crucial element for the society to progress. Recently, it has become the talk of the town as it is facing a challenging reality, that of virtual teaching introduced due to the pandemic precautions taken by the education bodies worldwide. It is quite obvious that extreme situations bring flashes that may blind or inspire us and this is the case in present days. We teachers, professors, and educators have spent many hours within the classroom or teaching environments and outside ruminating, pondering, discussing the best teaching methodology that inspires, draws students' attention and enhances their involvement during teaching/learning activities; we have invested our knowledge and experience on quite a considerable number of elaborated articles, but all these years it has never crossed our mind that we as teachers will be ever faced with such crashing reality. We have always considered the introduction of technology (computers, interactive boards, etc) as an assisting tool and not as the only and most important mean of disseminating and acquiring knowledge. So, the aim of this article is to reconsider the methodology of teaching English as a foreign language and the moribund and distressed situation it has fallen into lately. How we ought to motivate students if we have to overcome the mask and computer screen obstacle?
\end{abstract}

Keywords: teaching EFL, pandemic teaching, virtual teaching, passive learning, motivating students

\section{Introduction}

\section{An Overview of Methods and Approaches Implemented by English Language Teacher Within the Classroom}

Nowadays English is branded the leading language dominating, almost all social, economical, historical and cultural domain. It is estimated a considerable increase in its spread as one to three are interested in learning English as a foreign language. There is a growing tendency in parents (Albanian ones make no exception) to decide on their children taking up learning English as a foreign language. Once children get involved in English learning process they realize that it is not an easy task, but a real hard-won.

On the other hand, there is such a burden on teachers as to come out successfully in their humble mission of English teaching. As so this two-pronged process asks for a number of teaching methods to be applied within the classroom. 
1. Direct Method - First established in France and Germany in early 1900 known as the natural approach, focusing mostly on developing the oral skills. It forbids the usage of native language and encourages the students to figure out the rules themselves. It is quite alike to the correcting and praising theory of the first language acquisition as students would be corrected in case they make mistakes; praised when they use language correctly.

2. Grammar Translation - It is known as the traditional or classical way of teaching English as a foreign language. It was first introduced during the $18^{\text {th }}$ and $19^{\text {th }}$ century in Germany, mainly adopted for teaching classical languages as Latin and Greek. According to Kim (2008) it is a traditional and ancient teaching method. Larsen-Freeman and Anderson stated that in grammar translation method, both teachers and students have a traditional role. Namely, teachers provide grammar rules with examples and ask the students to memorize and use this rules in exercises. This method put the emphasis on "knowing" something about the language (competence) rather than "doing" anything with that knowledge. It also highlights the importance of written work over oral production urging Kim in stating that it does not exercise communication or listening comprehension. Due to the above short description of Grammar translation we will conclude with the following description as a method of "Knowing and Accuracy Emphasis at the Expense of Doing and Fluency".

3. The Audio-Lingual Method - also known as the New-key-method is based on the behaviorist approach, according to which constant imitation, reinforcement or repetition helps toddlers acquire the mother tongue and a child or adult learn a foreign language. It shares striking similarities with Direct Method, but the distinction lays on the fact that Direct Method teaches vocabulary, whereas the Audio-Lingual Method teaches grammar.

4. The Structural Approach - it focuses mostly on teaching grammar, specifically English sentences complex rules that differ or make this language distinguishable from the students' mother tongue. So, for a beginner to learn how to built and use present continues he should have been taught how to conjugate the verb "to be"

5. Immersion - According to Baker (1993) is a method of teaching a second language in which the learners second language (L2) is the medium of classroom instructions .Such an approach asks for an English speaking environment for a student to be exposed to English language not only within the classroom, but also when he gets out in the street, school, bar, restaurant, home, close friends company, etc. Full immersion is difficult but not impossible to be achieved (the case of immigrants that do not speak their mother tongue, but instead they express themselves in a target foreign language.

6. Communicative language teaching approach - It enjoys great popularity as it is the most widely accepted approach to a classroom based on foreign language teaching. CLT it is believed to be the most effective theoretical model in English language teaching since early 1970s. It highlights the students' ability to communicate various functions as asking, answering, making requests, describing, narrating and comparing. Task assignment and problem solving are its main operating means. It also stresses the fact that grammar is not taught in isolation, error correction is de-emphasized favoring the theory that students will naturally develop accurate speech through the frequent use. They develop fluency through communication rather than by analyzing it, 
7. Task-based learning approach - It is a refinement or extension of the communicative approach focusing on the completion of the specific tasks. Students use language that they know to fulfill a variety of assignments, acquiring new structures, forms and vocabulary

The approaches treated so far may easily fall into various subdivisions as: student centered versus teachers centered; or vocabulary focused versus grammar focused; traditional versus contemporary. They make up a considerable number of approaches that in order to clarify a teacher during his performance it bewilders or fills him with consternation which one is the most appropriate, effective and productive. According to Nunan $(1989 ; 1991)$ "It has been realized that there never was and probably never will be a method for all, and the focus on recent years has been on the development of classroom tasks and activities which are consonant with what we know second language acquisition, and which are also keeping with the dynamics of the classroom itself."

Such a statement hold true as all the above second language teaching methods and approaches, if treated in isolation provide concrete shortcomings as each of them tend to overemphasize one of the four skill (reading, writing, speaking, listening) at the expense of the others. In this context it is the duty of an experienced or devoted teacher to be very astute at integrating the above methods, techniques or approaches in achieving his teaching target and motivating and enhancing students learning attitude. So, he tends to appropriate and exploit all possible methodologies (sometimes involuntary or unconsciously) at the right time, for the right activity and to the benefit of those students whose learning style requires a certain approach.

\section{Teachers and Students Amid Web-Based Teaching and Learning Influence}

While skimming through various informative materials on second language teaching, a researcher can easily infer that such a notion refers to general principles, pedagogy and management strategies applied by the teacher, within the classroom resided by students. Pursuant to, the teaching-learning process asks for a close interaction among teachers and students within a confided environment, in this case a classroom.

Furthermore, the teacher mainly serves the roles of a facilitator, counselor, group processing manager. His utmost task is to impart knowledge, whereas the students' obligation is to acquire and further enhance the knowledge transmitted. In this context, what brings all the above teaching methods close together is their sole focus on knowledge transmission. For the knowledge to be successfully delivered or the sending-receiving process to thrive the burden falls mostly on the teachers, who lately have also considered the fact of making teaching an attractive engagement.

That is why by the early $21^{\text {st }}$ century there have been made serious attempts to introduce technology in the teaching -learning process. Teachers and researchers have contributed a great deal of papers on the positive and stunning effects that technology such as: video projectors, computers, TV sets, CD players, interactive boards had on English teaching. They mostly emphasized the fact that students found their in-class application attractive, motivating, less strenuous has they accomplished their assignment within a click. When we (teachers of English language from the Gjirokastra region, Albania) first experimented technology (as an assisting tool not as a teaching- learning approach) we witnessed an incomparable enthusiasm on the part of the students every time they had to enter the lab room to experience the programmed tasks on English or to complete their unit tests online. 
Apart from the enthusiasm it was also witnessed that they performed better, maybe due to the captivating screen effect or lack of emotions taking it as an entertaining activity and so doing they freed themselves from the stifling feeling that a test produced or distributed traditionally on papers causes.

The enthusiasm instilled in teachers was shattered with a while as they were expressing misgivings on the consequent shortcomings such as the fact that students are becoming lazy performers due to their technological addiction. The overlook the English words written form and their pronunciation. These skills are left to students' inclination and their memorizing capacities. So the moment the enthusiasm died down we as teachers discussed it would be better to rely on a natural fusion of all the above methods, approaches, techniques and assisting or facilitating means according to the skills, knowledge and information we want to disseminate no matter if they are considered quaint anachronism, old-fashioned, traditional, modern, contemporary or up to date.

\section{Present Situation in the Teaching-Learning Process}

The moment we believed that we have reached a certain consensus among us or within our conscience the new pandemics imposed a new teaching and learning reality which was solely a web-based one. For us it was as difficult as hauling up a steep hillside taking into consideration the Albanian reality, a post-communist country suffering at least a 30-year social, economic and cultural transition.

In a matter of weeks Covid 19 changed the way our children were educated worldwide. It has been estimated that 1.2 billion children worldwide in 186 countries were affected by school closure an had to resort to what is labeled as distant learning, virtual learning, online learning or at-home learning. Consequently students had to rely on internet based platforms as google classroom, skype, zoom, whats app, viber, e-mail or mass media. Let's mention here the case of $\mathrm{BBC}$ launching a new daily education program hosting celebrities to deliver the lecture (lesson0. According to Alice Webb (the BBC head of children's program) "It is vital that every child is able to continue learning, and the lessons we are putting on will make sure they have fun."

Taking into account the fact that this unexpected and sudden pandemic situation took us by surprise, it was considered the best solution ever and the teachers and other valuable contributors' efforts have to be appreciated.

Personally speaking, apart from the appreciation, I do not want to fall on self-satisfaction and praise the "pandemic teaching" as a present priority or the approach that will shape education for better. Even though there are a great number of educators, mainly from well-developed countries that find at-home or virtual teaching not as a temporary solution but as a future innovation. I want to represent an exceptional case and critically analyze what it means for teachers, students of third world countries (the case of Albania)

As a teacher of English and parent of two school girls I totally support some of the statements made by the American parents defining "Zoom school as a typical nightmare or merely hell.

Related to, I have raised certain simple question that when mirroring the reality sound hard to give an appropriate answer:

How are we supposed to teach a 6-9 years old child how to conjugate an English verb in present simple; how its negative and interrogative structure is formed from home where we 
do not dispose a board or in case the screen image is distorted or if there is lack of internet? How are we supposed to explain the introduction of the auxiliary verb "to do" in negative and interrogative sentences, where it came from and the role as they do not experience such constructions in Albanian.

How are we supposed to teach a 6-9 years old child the correct pronunciation of English words when the sound is distorted or we are wearing masks?

How are we supposed to check English words and sentences writing if, even though we are dictating words by the screen students can easily cheat?

How are to assign tasks in group or pairs (such as making on the spot dialogues or other speaking activities aiming at using the English vocabulary correctly) if the internet signal comes and goes?

Teaching is interaction.

How are students supposed to make instant questions on topics or issues they find confusing or express their at the moment opinion on certain topics they find interesting.

"Everyone is fine with every technology as long as it doesn't cause any trouble", but this is not our case. The trouble it causes are not of technological origin, but also psychological, social and emotional. Psychology highlights the fact that social context, interpersonal relationship and emotional well-being are important to students' learning. For the time being our children and students are having limited access to their classmates as they are attending at-home learning or are students of what we lately named "bubble classes". Such unwilling withdrawal can affect children's social and emotional well-being which led inexorably to a poor performance. To understand this let's mention here the importance of role playing and learning through playing as integral and very productive classroom patterns in English language teaching. They ask for interpersonal relationship and communication among various students which is hardly imposible to be realized virtually.

To sum it up, my opinion is that teaching and learning are more than: filling a form in Excel; writing an essay in Word; sending an E-mail; listening to Music; playing a Game; surfing the Net; watching a Film; thumbing up a friend's video posted in Facebook; making a comment in Twitter, etc. It is our children's psychological, emotional, educational and economical wellbeing; it is the future society the today humans want to project.

Teaching English is not only related to performance but according to what Chomsky inferred, there is no performance without competence; there is no doing without knowing; no fluency without accuracy.

To better fulfill our humble mission we as teachers of today and projectors of the future, before reshaping education with such threadbare excuses as "the today education system is loosing relevance" ought to bear in mind the statement made for BBC by a student of Riverside School in Barking "School return: It is going to get me back on track"

\section{References}

[1] Celce-Murcia, M (2014) An Overview of Language Teaching Method and Approaches. in M. Celce-Murcia, D. M. Brinton \& M.a. Snow "Teaching English as a Second or Foreign Language" (4th Ed.) Boston, MA.

[2] Hymes D. (1972). Models of Interaction of Language and Social Life. in J. J. Gumperz 
\& D. Hymes Directions is Sociolinguistics, New York Holt Inehart \&Winston.

[3] Kim. H. J(2008) Grammar Translation Method in Josue M Gonzales (Ed) Encyclopedia of Bilingual Education Vol.1 Thousand Oaks, CA: SAGE Publications

[4] Larsen -Freeman D., \& Anderson M., (2011) Techniques and Principles in Language Teaching ( $3^{\text {rd }}$ Ed), New York, Oxford University Press.

[5] Nunan D., (1991), Language Teaching Methodology a Textbook for Teachers. Hemel Hempstead: Prentice Hall.

[6] Richards J.C \& Rogers T. S. (2001) Approaches and Methods in Language Teaching ( $2^{\text {nd }}$ Ed.), Cambridge, Cambridge University Press.

[7] Zhou G. \& Niu X. (2015) Approaches to Language Teaching and Learning, Journal of Language Teaching and Research, Vol 6, No 4, Pp 798-802. ISSN 1798-4769

[8] Renau L.M., a Review of the Traditional and Current Language Teaching Method, International Journal of Innovation and Research in Education Sciences, Vol. 3, Issue 2, ISSN (Online) 2349-5219.

[9] Li. C \& Lalani F., the Covid-19 Pandemic Has Changed Education Forever, World Education Forum, 2020.

[10] Tam G., \& El-Azar D., 3 Ways The Coronavirus Pandemic Could Reshape Education, China Daily CDIC, 2020. 